\title{
Futures Markets and Farmers Welfare: Are They in Sync?
}

\section{Sudhakar Gummula}

Agri Business and Trade Consultant, Hyderabad, India

Corresponding author: s.gummula@yahoo.com

\begin{abstract}
Commodity derivative markets, are expected to be alternative markets to physical or spot markets where producers including farmers will be able to foresee market prices of the commodities they are about to produce much in advance of the actual production takes place. The recently introduced commodity options trading instruments are expected to provide a further boost to the hedging and risk management capabilities of commodity derivative markets in India, as option contracts, unlike futures contracts, work on the criteria of unlimited gains with limited losses opportunity. Nevertheless, the risks associated with primary agricultural production are long-term in nature and the current system of commodity derivatives trading instruments available in India needs an improvement to address these long-term aspects so that farmers will be able to take advantage of the system.
\end{abstract}

Keywords: Risk management, Agricultural markets, Commodity

Agricultural markets in India have seen a significant change with the introduction of electronic trading in futures contracts on national level commodity exchanges in the year 2003. Though futures trading in agricultural commodities is not new, it was limited to a few groups of people consisting of processors and traders who are active in physical markets. And the introduction of electronic trading with settlement procedures on par with the stock trading attracted a new set of traders consisting of financial investors, speculative hoarders and the consumers. Nevertheless, the participation of farmers in futures trading remained limited despite the fact that it was supposed to provide them with advance price forecasts and thus make forward sales of their crops.

Indian commodity trading community has recently got a new avenue for investing, hedging and speculating on commodity prices in the form of options contracts on existing commodity futures contracts. Unlike futures contracts - where there is a risk of unlimited losses - these options instruments are expected to act as insurance against value loss due to price variation - with losses limited to the premium paid for purchasing the instrument.
Although options trading is not new to Indian traders especially those who are regular in stock markets, these commodity options are slightly different in the sense that the underlying itself is a derivative of a physical commodity i.e., a futures contract, unlike the stock options where the underlying is stock itself. Further, these commodity options are expected to devolve into a futures transaction on the expiry date.

Unlike the commodity option contracts traded on global commodity exchanges like Chicago Mercantile Exchange (CME), Inter Continental Exchanges (ICE) - the future contracts traded on whose platforms are benchmarks for those traded on Indian commodity exchanges - the options contracts offered here are of European style, which can be exercised only on the date of option expiry. This is also the style followed for stock options and is more familiar to Indian brokerage community that has expertise in stock markets.

Commodity derivative markets, are expected to be alternative markets to physical or spot markets where producers including farmers will be able to foresee market prices of the commodities they are about to produce much in advance of the actual 
production takes place. And in the process, they will be able to control any significant variation in their realized incomes. However, these markets being virtual in nature and as physically sold commodities still need to be delivered for final consumption, there is a pressing need for these markets to be an accurate representation of the physical markets. In the options segment too, the premiums that are paid or offered must be able to fulfil the requirement of farmers and other hedgers alike, apart from possessing the ability to better represent the existing market conditions.

This article tries to examine the current derivative market trading system and find out if they are benefiting farmers and other hedgers and makes suitable suggestions for improvement. Rest of the article is organized as follows. Section 2 discusses the efficiency of futures markets, section 3 highlights the importance of options market for farmers, section 4 compares the European and American type of option contracts, section 4 concludes the topic.

\section{Efficiency of commodity futures markets}

National level electronic commodity futures exchanges launched in the year 2003, are expected to provide farmers with the trend of prices of various commodities well in advance, enabling them to plan their cropping pattern as well, although in an indirect way (PIB, 2004) through the mechanism called price discovery and efficient price dissemination.

Research studies are conducted to know if the futures market prices can be used as an efficient forecast for the future spot price. The studies on international markets showed mixed results depending on market/ commodity and the time period analyzed. For instance, Carter and Mohapatra (2008) found the US hog futures market prices as efficient forecasts of future spot prices. McKenzie et al. (2002) found US rice futures market prices as efficient, while Mohan and Love (2004) found NYBOT coffee futures as inefficient. Some studies on Indian commodity markets are also conducted. Gupta and Varma (2016) found stronger information flow from the rubber futures to spot markets, indicating price discovery happening in futures markets. Ranganathan and Ananthakumar (2014) found short-run market inefficiencies and also a presence of a time-varying risk premium in soybean futures markets. Shihabudheen and Padhi (2010) analyzed gold, silver, crude oil, castor seed, jeera, and sugar. While sugar found to be inefficient due to low trading volumes others are found to be efficient. Kumar and Pandey (2013) have analyzed four agricultural (soybean, corn, castor seed and guar seed) and seven non-agricultural (gold, silver, aluminium, copper, zinc, crude oil, and natural gas) commodities. As far as long-run efficiency is concerned, the authors find that near-month futures prices of most of the commodities are cointegrated with the spot prices. The cointegration relationship is not found for the next to near months futures contracts, where futures trading volume is low. The authors find support for the hypothesis that thinly traded contracts fail to forecast future spot prices and are inefficient.

Although the methodology "efficient market hypothesis" employed for the studies on Indian as well as international markets, is same there is a difference in data that is analyzed. And the difference is mostly in terms of lag length between the futures price and cash/ spot prices. In international market studies while it extends up to one year, in Indian markets it is not more than two months and mostly one month. And it is more to do with the data generation process adopted by Indian commodity exchanges unlike the one adopted by global commodity exchanges. Further, most of the Indian commodities were found to have unilateral causation from futures to spot markets, despite the fact that the information available in such a short lag length would be same for both the markets.

Extending the discussion a little further, can we use Indian commodity futures prices as forecasts for future spot prices, in the case of primary agricultural producers i.e. the farmers? Let us consider the case of sugarcane that is one of the longest duration crops. 99 per cent of sugarcane sowings will be completed by March/ April every year and harvest commences in December. That means if a farmer has to base his cropping intentions on futures market prices, he needs an active and liquid December contract in the month of January/ February itself. In Punjab and Haryana wheat sowings starts in October and harvest commences after Baisakhi that means farmers need an active April/ May futures contract in the months of September/ October itself. Glancing through the data on existing agricultural 
commodity futures markets, the maximum life of any contract is six months and by looking at the actual trade data, no contract is active for more than a month, which means they are not capable of providing an efficient price forecast beyond a month.

\section{Usage of commodity options market for farmers in India}

Securities Exchange Board of India (SEBI), the regulator for commodity derivatives market in India has permitted one commodity from nonagriculture and one from agriculture sector for options trading on commodity derivatives exchange platforms, where the underlying futures contracts have substantial trading volume. Subsequently, gold and guar seed commodity options contracts were launched by Multi Commodity Exchange of India (MCX) and National Commodity Derivative Exchange (NCDEX), respectively. And to begin with the option style is European, i.e. they can be exercised only on the expiry date.

Guar seed once a little-known commodity came into limelight when it found new demand from shale oil/ gas industry in the United States causing a sharp rise in volatility of prices as well as trading volumes on commodity exchanges. With guar seed being directly linked to world's most sensitive and highly volatile commodity, the crude oil, it has to face a ban on exchange trading, when the price movements went out of control (Reuters, 2012). However, it retained trading volumes, after the ban was lifted and eventually trading in options contracts is also launched, early this year. Although a minor product in comparison to total farm production in India and bulk of the production confined to Rajasthan, the price movements of the same are still important, as it is a direct competitor for other sensitive commodities like pulses, in terms of area under the crop to be sown by farmers. Like other agricultural commodities it is also prone to seasonal fluctuations in prices and protecting farmers' income would be important to ensure sustainable production of the same.

Fig. 1 depicts the seasonality ${ }^{1}$ in guar seed prices, which shows high prices being quoted during the months of May through September and starts falling thereafter coinciding with crop harvest. Fig. 2 depicts the daily prices from January 1, 2015, to
January 20, 2017. It has reached a high of ₹ 5200 per quintal - although lower than the astronomical peak of ₹ 30000 per quintal realized in the year 2012 - during the month of May 2015 after forming a seasonal low in the month of February 2015. (Data source: NCDEX)

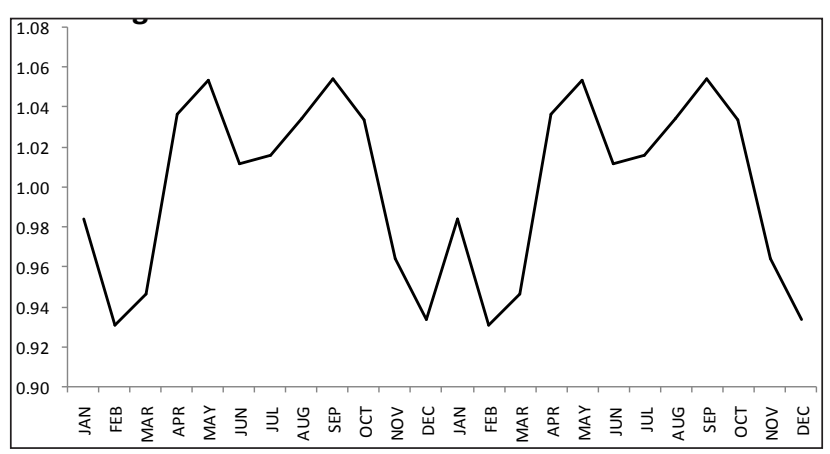

Fig. 1: Seasonal Index of Guar seed prices

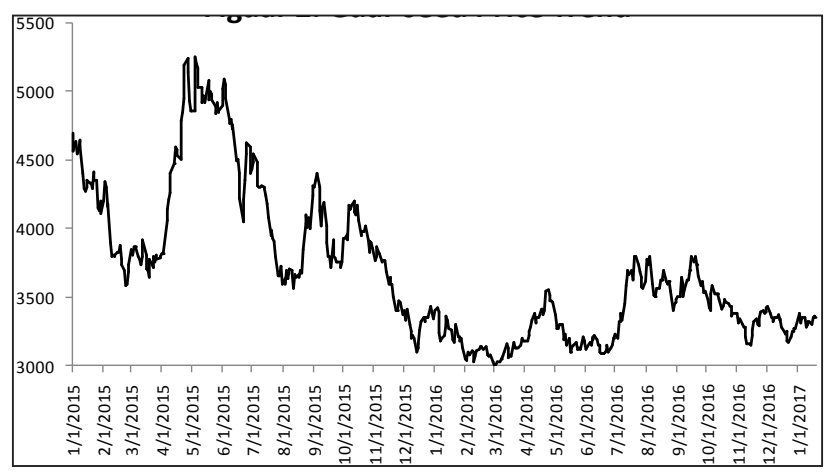

Fig. 2: Guar seed price trend (INR/Qtl)

Assuming that a farmer is capable of storing the grain so that he can realize better price later in the season and he is also happy with the price of ₹ 5000 a quintal, the farmer would be better off if he realizes the same or a bit higher price in the same period next year i.e. May 2016. Going by the seasonal trends a fair expectation would be that prices will reach the desired level after a decline during the harvest season. However, in the event prices could not reach the expected peak farmer revenues may not match previous year's level in which case he may need some form of hedging either through futures or options market, although options market would be more preferable as it would come with the option of limiting the losses to the premium paid for purchase of the contract.

\section{Choosing between American and European Options}

The following is a discussion on pros and cons of 
using options as a hedging platform with realized guar seed prices between May 2015 and May 2016 as depicted in Fig. 2. Spot prices are considered as underlying futures contract prices as we don't have such a long maturity futures contract prices. Only put option is analyzed as any farmer is expected to be a seller in the market. Although writing a call option would result in the same trade position, it is much riskier than selling a futures contract due to its limited profits and unlimited losses in nature. Both European, as well as American styles of options, are analyzed. European option premiums are calculated using the formula given by Black (1976), while American option premiums are calculated using the formula given by Bjerksund and Stensland (2002). Annualized daily volatility values are estimated using the IGARCH $(1,1)$ model. One month Mumbai Interbank Offer Rate (MIBOR) is taken as the risk-free rate.

On May 6, 2015 guar seed spot price basis Jodhpur market is at ₹ 5200 per quintal and assuming farmer purchased a put option with an exercise price of ₹ 5000 per quintal and maturity date of April 22, 2016 , by paying a premium of ₹ 845 per quintal for American or ₹ 824 per quintal for European option. As per the realised prices the put option, which was out of the money (OTM) on the date of purchase, turned deep in the money (ITM) over the period as the underlying prices have fallen sharply, reaching a low of ₹ 3000 per quintal by March 1, 2016. At this stage, there are two months left for the option to expire. And it is worthwhile to exercise or square off the option due to the fact that the time value which is an important component of the option premium, being a non-linear function decays at a faster rate (unless volatility works in its favour) as the option approaches maturity date. As we can see from the table 1 , an early exercise (a feature available only on American options) would result in a net positive realization, which will be shown up as a mark to market (MTM) in the futures position. Also, even if one wants to square off, the returns on American options are better than European options.

Any trader, either buyer or seller of options is exposed to the risk of potential loss if the market moves against the direction of the trade he entered into. Although such losses are limited to 'premium paid' to a buyer of an option contract, they may mount in the long run and may become an additional cost to be considered - like theft or fire insurance costs - in case of hedgers who have physical market operations. And for any hedger it would be appropriate to exercise the option as and when it achieves the intended target of achieving a certain level of protection against the unexpected price movement. However, it is worthwhile to exercise the options only when they are ITM. In other words, for any hedger to benefit from options market, he should trade ITM options or OTM options that can turn ITM after the lapse of a certain amount of time.

Understanding how the value of a commodity changes relative to the change in a given parameter is key to hedging (Lyuu, 2002). The parameters

Table 1: Comparison of American and European options (Strike price is $\mathrm{X}=5000$ )

\begin{tabular}{|c|c|c|c|c|c|c|c|c|}
\hline \multirow[b]{2}{*}{ Purchase on } & \multirow[b]{2}{*}{$\begin{array}{c}\text { Future } \\
\text { price }\end{array}$} & \multicolumn{4}{|c|}{ Premium paid } & & \multirow[b]{2}{*}{$\begin{array}{l}\text { Annualised } \\
\text { Volatility } \sigma\end{array}$} & \multirow[b]{2}{*}{$\begin{array}{c}\text { Risk free } \\
\text { rate } \%\end{array}$} \\
\hline & & American & European & American & European & & & \\
\hline $5 / 6 / 2015$ & 5200 & 845.04 & 824.03 & 845.04 & 824.03 & & 0.4337 & 8.02 \\
\hline \multirow[b]{3}{*}{ Sale as on } & \multicolumn{4}{|c|}{ Returns from } & \multirow{3}{*}{\multicolumn{2}{|c|}{$\begin{array}{c}\text { Excess } \\
\text { gain from } \\
\text { squaring off } \\
\text { American } \\
\text { option } \\
\end{array}$}} & \multirow{3}{*}{$\begin{array}{l}\text { Annualised } \\
\text { Volatility } \sigma\end{array}$} & \multirow{3}{*}{$\begin{array}{c}\text { Risk free } \\
\text { rate } \%\end{array}$} \\
\hline & \multicolumn{2}{|c|}{ Exercise * } & \multicolumn{2}{|c|}{ Square off } & & & & \\
\hline & $\begin{array}{c}\text { Future } \\
\text { price }\end{array}$ & American & European & American & & & & \\
\hline $12 / 14 / 2015$ & 3100.00 & 1054.96 & - & 1054.96 & 1012.24 & 42.72 & 0.3102 & 7.27 \\
\hline $2 / 11 / 2016$ & 3073.55 & 1081.41 & - & 1081.41 & 1064.07 & 17.34 & 0.2897 & 7.31 \\
\hline $3 / 1 / 2016$ & 3000.00 & 1154.96 & - & 1154.96 & 1145.42 & 9.54 & 0.2511 & 7.58 \\
\hline $4 / 22 / 2016$ & 3543.55 & 611.41 & 632.42 & 611.41 & 632.03 & -20.62 & 0.2139 & 7.01 \\
\hline
\end{tabular}

* net realisation over current futures price after adjusting for premium paid, which will be shown as MTM in futures position; Prices in INR/Qtl; data sources: NCDEX and RBI. 
that influence the premium value of an option are, the price of the underlying instrument, time to expiration, change in interest rates and change in volatility of underlying prices. The sensitivity of premium value to changes in these parameters is measured using well-defined formulas, commonly referred to as Option Greeks. The Delta $(\delta)$ measures the change in option price for Re. 1 change in futures price; Gamma $(\gamma)$ measures the change in $\delta$ for a Re. 1 change in futures price; theta $(\theta)$ measures the decline in option price for a 30 day decline in time to option expiration; Rho (o) measures the change in option price for a $1 \%$ change in interest rate; Vega (v) measures the change in option price for a 0.1 change in standard deviation (volatility) of future price (Shastri and Tondon, 1986). These sensitivities are calculated for put options of both American (Bjerksund and Stensland, 2002) and European (Black, 1976) models and are presented in the tables 2 to 5; while calculating a particular sensitivity, the parameters that affect other sensitivities are kept constant. For example, while calculating $\delta$, only futures prices are varying while all other parameters are kept constant.

As a farmer/ hedger or as a trader one would expect the options market to better reflect the changing market conditions for all options. As we can see from table 2, premium values for European options are closer to American options only when the options are OTM, and the difference is larger when they are at the money (ATM) or ITM. Any hedger who prefers to trade ITM options would expect them to better reflect the changing market conditions, in which case American options are preferred.

Over longer periods, as the foreseeable risks would be higher one would expect options to reflect the same. From table 3, we can see that European option premiums are closer to American models for only short maturity options, while American options better reflect changes in the long-term market conditions as well.

Although interest rates have fallen recently in India they are still higher than interest rates in developed countries and there is always an upward risk and one would expect options to better reflect higher interest rates. As it can be seen from table 4 European models are closer to American models for pricing options on futures only when the interest rates are low, a pattern observed by Shashtri and Tondon who calculated American option premiums using their own model.

As an option seller when expected volatility is high one would expect a higher premium to be received, while a buyer expects option premiums to better reflect growth in volatility once he purchases the contract. It can be seen from table 5 European

Table 2: Change in put option with a change in futures price

\begin{tabular}{|c|c|c|c|c|c|c|c|c|c|c|c|c|}
\hline \multirow{3}{*}{$\begin{array}{l}\text { Futures } \\
\text { price }(F)\end{array}$} & \multicolumn{12}{|c|}{$X=400, t=360$ days, $r=8 \%, \sigma=0.30$} \\
\hline & \multicolumn{2}{|c|}{ Premium } & \multicolumn{2}{|c|}{$\delta$} & \multicolumn{2}{|c|}{$\gamma$} & \multicolumn{2}{|c|}{$\theta$} & \multicolumn{2}{|c|}{ @ } & \multicolumn{2}{|c|}{$v$} \\
\hline & $\begin{array}{l}\text { Europe- } \\
\text { an }\end{array}$ & $\begin{array}{c}\text { Ameri- } \\
\text { can }\end{array}$ & $\begin{array}{c}\text { Europe- } \\
\text { an }\end{array}$ & $\begin{array}{l}\text { Ameri- } \\
\text { can }\end{array}$ & $\begin{array}{l}\text { Europe- } \\
\text { an }\end{array}$ & $\begin{array}{l}\text { Ameri- } \\
\text { can }\end{array}$ & $\begin{array}{c}\text { Europe- } \\
\text { an }\end{array}$ & $\begin{array}{c}\text { Ameri- } \\
\text { can }\end{array}$ & $\begin{array}{c}\text { Europe- } \\
\text { an }\end{array}$ & $\begin{array}{c}\text { Ameri- } \\
\text { can }\end{array}$ & $\begin{array}{c}\text { Europe- } \\
\text { an }\end{array}$ & $\begin{array}{c}\text { Ameri- } \\
\text { can }\end{array}$ \\
\hline 300 & 100.84 & 104.47 & -0.7328 & -0.7831 & 0.0030 & 0.0035 & 0.3207 & 0.6604 & -0.9945 & -0.3730 & 7.870 & 7.266 \\
\hline 325 & 83.48 & 86.02 & -0.6544 & -0.6918 & 0.0033 & 0.0038 & 0.7312 & 0.9859 & -0.8234 & -0.4097 & 10.241 & 10.064 \\
\hline 350 & 68.16 & 69.90 & -0.5708 & -0.5976 & 0.0034 & 0.0038 & 1.0836 & 1.2787 & -0.6723 & -0.3971 & 12.254 & 12.337 \\
\hline 375 & 54.94 & 56.12 & -0.4870 & -0.5057 & 0.0033 & 0.0036 & 1.3511 & 1.5013 & -0.5419 & -0.3590 & 13.699 & 13.913 \\
\hline 400 & 43.77 & 44.56 & -0.4073 & -0.4201 & 0.0031 & 0.0033 & 1.5227 & 1.6376 & -0.4318 & -0.3105 & 14.484 & 14.743 \\
\hline 425 & 34.52 & 35.04 & -0.3348 & -0.3434 & 0.0027 & 0.0029 & 1.6010 & 1.6880 & -0.3404 & -0.2601 & 14.624 & 14.879 \\
\hline 450 & 26.96 & 27.31 & -0.2709 & -0.2766 & 0.0024 & 0.0025 & 1.5987 & 1.6638 & -0.2659 & -0.2129 & 14.208 & 14.434 \\
\hline 475 & 20.89 & 21.12 & -0.2162 & -0.2201 & 0.0020 & 0.0021 & 1.5332 & 1.5814 & -0.2061 & -0.1710 & 13.365 & 13.552 \\
\hline 500 & 16.08 & 16.23 & -0.1706 & -0.1731 & 0.0017 & 0.0017 & 1.4234 & 1.4586 & -0.1586 & -0.1355 & 12.233 & 12.382 \\
\hline
\end{tabular}

Notes: $X$ is Strike price, $F=$ current Futures Price, $t=$ time to maturity, $r=$ risk free rate, $\sigma=$ annualized volatility; $\delta$ measures the change in option price for Re. 1 change in futures price; $\gamma$ measures the change in $\delta$ for a Re. 1 change in futures price; $\theta$ measures the decline in option price for a 30 day reduction in time to option expiration; $\rho$ measures the change in option price for a $1 \%$ change in interest rate; $v$ measures the change in option price for a 0.1 change in standard deviation of future price. 
Table 3: Change in put option with a change in time to expiration

\begin{tabular}{|c|c|c|c|c|c|c|c|c|c|c|c|c|}
\hline \multirow{3}{*}{$\begin{array}{c}\text { Days to } \\
\text { expira- } \\
\text { tion }\end{array}$} & \multicolumn{12}{|c|}{$X=400, F=400, r=8 \%, \sigma=0.30$} \\
\hline & \multicolumn{2}{|c|}{ Premium } & \multicolumn{2}{|c|}{$\Delta$} & \multicolumn{2}{|c|}{$\gamma$} & \multicolumn{2}{|c|}{$\theta$} & \multicolumn{2}{|c|}{$\varrho$} & \multicolumn{2}{|c|}{ 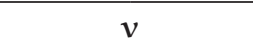 } \\
\hline & $\begin{array}{c}\text { Europe- } \\
\text { an }\end{array}$ & American & $\begin{array}{l}\text { Europe- } \\
\text { an }\end{array}$ & $\begin{array}{l}\text { Ameri- } \\
\text { can }\end{array}$ & $\begin{array}{c}\text { Europe- } \\
\text { an }\end{array}$ & $\begin{array}{l}\text { Ameri- } \\
\text { can }\end{array}$ & $\begin{array}{l}\text { Europe- } \\
\text { an }\end{array}$ & $\begin{array}{c}\text { Ameri- } \\
\text { can }\end{array}$ & $\begin{array}{l}\text { Europe- } \\
\text { an }\end{array}$ & $\begin{array}{l}\text { Ameri- } \\
\text { can }\end{array}$ & $\begin{array}{c}\text { Europe- } \\
\text { an }\end{array}$ & $\begin{array}{l}\text { Ameri- } \\
\text { can }\end{array}$ \\
\hline 30 & 13.63 & 13.64 & -0.4797 & -0.4802 & 0.0115 & 0.0115 & 6.7215 & 6.7983 & -0.0112 & -0.0095 & 4.541 & 4.543 \\
\hline 60 & 19.14 & 19.18 & -0.4695 & -0.4709 & 0.0081 & 081 & 4.6543 & 4.7056 & -0.0315 & -0.0259 & .374 & 384 \\
\hline 90 & 23.29 & 23.36 & -0.4611 & -0.4635 & 0.0065 & 0.0066 & 3.7207 & 3.7734 & -0.0574 & -0.0462 & .748 & .770 \\
\hline 120 & 26.70 & 26.82 & -0.4536 & -0.4570 & 0.0056 & 0.0057 & 3.1542 & 3.2127 & -0.0878 & -0.0693 & 8.879 & 8.917 \\
\hline 150 & 29.65 & 29.82 & -0.4468 & -0.4512 & 0.0050 & 0.0051 & 2.7610 & 2.8266 & -0.1219 & -0.0947 & 9.853 & 9.909 \\
\hline 180 & 32.26 & 32.49 & -0.4403 & -0.4459 & 0.0045 & 0.0046 & 2.4662 & 2.5392 & -0.1591 & -0.1219 & 10.713 & 10.790 \\
\hline 210 & 34.60 & 34.91 & -0.4343 & -0.4410 & 0.0042 & 0.0043 & 2.2335 & 2.3140 & -0.1991 & -0.1506 & 11.485 & 11.586 \\
\hline 240 & 36.74 & 37.13 & -0.4285 & -0.4363 & 0.0039 & 0.0040 & 2.0434 & 2.1310 & -0.2416 & -0.1807 & 12.186 & 12.314 \\
\hline 270 & 38.70 & 39.18 & -0.4229 & -0.4320 & 0.0036 & 0.0038 & 1.8837 & 1.9785 & -0.2863 & -0.2118 & 12.829 & 12.986 \\
\hline
\end{tabular}

Notes: same as table 2.

Table 4: Change in put option with a change in interest rates

\begin{tabular}{|c|c|c|c|c|c|c|c|c|c|c|c|c|}
\hline \multirow{3}{*}{$\begin{array}{l}\text { Interest } \\
\text { rates }\end{array}$} & \multicolumn{12}{|c|}{$X=400, F=400, t=360$ days, $\sigma=0.30$} \\
\hline & \multicolumn{2}{|c|}{ Premium } & \multicolumn{2}{|c|}{$\delta$} & \multicolumn{2}{|c|}{$\gamma$} & \multicolumn{2}{|c|}{$\theta$} & \multicolumn{2}{|c|}{ @ } & \multicolumn{2}{|c|}{$v$} \\
\hline & $\begin{array}{c}\text { Europe- } \\
\text { an }\end{array}$ & $\begin{array}{l}\text { Ameri- } \\
\text { can }\end{array}$ & European & $\begin{array}{c}\text { Ameri- } \\
\text { can }\end{array}$ & $\begin{array}{c}\text { Europe- } \\
\text { an }\end{array}$ & $\begin{array}{c}\text { Ameri- } \\
\text { can }\end{array}$ & $\begin{array}{c}\text { Europe- } \\
\text { an }\end{array}$ & $\begin{array}{c}\text { Ameri- } \\
\text { can }\end{array}$ & $\begin{array}{c}\text { Europe- } \\
\text { an }\end{array}$ & $\begin{array}{c}\text { Ameri- } \\
\text { can }\end{array}$ & $\begin{array}{c}\text { Europe- } \\
\text { an }\end{array}$ & $\begin{array}{c}\text { Ameri- } \\
\text { can }\end{array}$ \\
\hline $2 \%$ & 46.44 & 46.57 & -0.4322 & -0.4340 & 0.0032 & 0.0033 & 1.8445 & 1.8648 & -0.4581 & -0.3631 & 15.367 & 15.390 \\
\hline $3 \%$ & 45.99 & 46.21 & -0.4279 & -0.4314 & 0.0032 & 0.0033 & 1.7886 & 1.8231 & -0.4536 & -0.3517 & 15.216 & 15.276 \\
\hline $4 \%$ & 45.54 & 45.86 & -0.4237 & -0.4289 & 0.0032 & 0.0033 & 1.7336 & 1.7832 & -0.4491 & -0.3419 & 15.067 & 15.165 \\
\hline $5 \%$ & 45.09 & 45.53 & -0.4196 & -0.4266 & 0.0032 & 0.0033 & 1.6796 & 1.7448 & -0.4447 & -0.3330 & 14.919 & 15.056 \\
\hline $6 \%$ & 44.65 & 45.20 & -0.4155 & -0.4243 & 0.0031 & 0.0033 & 1.6264 & 1.7078 & -0.4404 & -0.3249 & 14.773 & 14.949 \\
\hline $7 \%$ & 44.21 & 44.88 & -0.4114 & -0.4222 & 0.0031 & 0.0033 & 1.5741 & 1.6721 & -0.4360 & -0.3175 & 14.628 & 14.845 \\
\hline $8 \%$ & 43.77 & 44.56 & -0.4073 & -0.4201 & 0.0031 & 0.0033 & 1.5227 & 1.6376 & -0.4318 & -0.3105 & 14.484 & 14.743 \\
\hline $9 \%$ & 43.35 & 44.26 & -0.4033 & -0.4181 & 0.0030 & 0.0033 & 1.4721 & 1.6041 & -0.4275 & -0.3039 & 14.342 & 14.644 \\
\hline $10 \%$ & 42.92 & 43.95 & -0.3994 & -0.4162 & 0.0030 & 0.0033 & 1.4224 & 1.5718 & -0.4233 & -0.2977 & 14.201 & 14.546 \\
\hline
\end{tabular}

Notes: same as table 2.

Table 5: Change in put option with a change in volatility

\begin{tabular}{|c|c|c|c|c|c|c|c|c|c|c|c|c|}
\hline \multirow{3}{*}{$\begin{array}{l}\text { Volatili- } \\
\text { ty }(\sigma)\end{array}$} & \multicolumn{12}{|c|}{$X=400, F=400, t=360$ days, $r=8 \%$} \\
\hline & \multicolumn{2}{|c|}{ Premium } & \multicolumn{2}{|c|}{$\Delta$} & \multicolumn{2}{|c|}{$\gamma$} & \multicolumn{2}{|c|}{$\theta$} & \multicolumn{2}{|c|}{ Q } & \multicolumn{2}{|c|}{$v$} \\
\hline & $\begin{array}{c}\text { Europe- } \\
\text { an }\end{array}$ & $\begin{array}{c}\text { Ameri- } \\
\text { can }\end{array}$ & $\begin{array}{c}\text { Europe- } \\
\text { an }\end{array}$ & $\begin{array}{c}\text { Ameri- } \\
\text { can }\end{array}$ & $\begin{array}{l}\text { Europe- } \\
\text { an }\end{array}$ & $\begin{array}{c}\text { Ameri- } \\
\text { can }\end{array}$ & $\begin{array}{l}\text { Europe- } \\
\text { an }\end{array}$ & $\begin{array}{l}\text { Ameri- } \\
\text { can }\end{array}$ & $\begin{array}{c}\text { Europe- } \\
\text { an }\end{array}$ & $\begin{array}{l}\text { Ameri- } \\
\text { can }\end{array}$ & European & $\begin{array}{c}\text { Ameri- } \\
\text { can }\end{array}$ \\
\hline 0.05 & 7.32 & 7.45 & -0.4529 & -0.4668 & 0.0186 & 0.0198 & 0.2569 & 0.2757 & -0.0722 & -0.0526 & 14.641 & 14.900 \\
\hline 0.10 & 14.64 & 14.90 & -0.4438 & -0.4575 & 0.0093 & 0.0099 & 0.5132 & 0.5511 & -0.1444 & -0.1049 & 14.628 & 14.890 \\
\hline 0.15 & 21.95 & 22.34 & -0.4346 & -0.4482 & 0.0062 & 0.0066 & 0.7685 & 0.8256 & -0.2165 & -0.1569 & 14.605 & 14.870 \\
\hline 0.20 & 29.24 & 29.77 & -0.4255 & -0.4388 & 0.0046 & 0.0049 & 1.0222 & 1.0986 & -0.2884 & -0.2085 & 14.574 & 14.839 \\
\hline 0.25 & 36.52 & 37.18 & -0.4164 & -0.4295 & 0.0037 & 0.0039 & 1.2737 & 1.3695 & -0.3602 & -0.2597 & 14.533 & 14.797 \\
\hline 0.30 & 43.77 & 44.56 & -0.4073 & -0.4201 & 0.0031 & 0.0033 & 1.5227 & 1.6376 & -0.4318 & -0.3105 & 14.484 & 14.743 \\
\hline 0.35 & 51.00 & 51.92 & -0.3983 & -0.4108 & 0.0026 & 0.0028 & 1.7684 & 1.9021 & -0.5030 & -0.3606 & 14.426 & 14.679 \\
\hline 0.40 & 58.20 & 59.24 & -0.3893 & -0.4014 & 0.0023 & 0.0024 & 2.0106 & 2.1625 & -0.5740 & -0.4100 & 14.360 & 14.602 \\
\hline 0.45 & 65.36 & 66.52 & -0.3804 & -0.3920 & 0.0020 & 0.0021 & 2.2486 & 2.4181 & -0.6447 & -0.4586 & 14.284 & 14.514 \\
\hline
\end{tabular}

Notes: same as table 2. 
model prices are close to the American model in situations when a futures contract is not very volatile, while American models better reflect high volatile conditions as well. A pattern observed by Shashtri and Tondon.

\section{CONCLUSION}

Indian commodity derivatives market has seen its spate of ups and downs. Seeing the pace at which closures of regional exchanges happening, it appears that only national and that too electronic exchanges are able to survive. And with the stock exchanges are also expected to launch their own commodity derivative trading platforms, a big boost - in terms of money that can be flown into these markets - to the segment is expected. Recently launched options trading on these national trading platforms is also expected to boost trading volumes, by bringing more participants to market especially those who are staying away due to high-risk exposure of futures markets.

Although put options are analyzed from the perspective of primary commodity producers, they are applicable to commodity buyers such as processors, exporters etc as long as the processed product prices have a direct correlation with primary products, like the soybean oil prices depend on the movement of soybean prices. The risk associated with the agricultural production is long-term in nature, and current futures market contracts are unable to cater to them. For instance, in case of Kharif season commodities, the only reliable information available for trading purposes is crop sowing data and monsoon rainfall data, which are used for predicting the crop production to be arrived and verified during the harvest months. There is no point in trading in a contract that expires between June and November months with the information that can be verified only during the month of December. Rescheduling the existing futures contracts to less than four per commodity per calendar year, while increasing the total life of each contract from existing 6 months to anywhere between 24 to 36 months, by eliminating all the contracts that expire during the respective crop growing season may help in shifting the speculative/ hedging activity to harvest month contracts, thus enabling producers to take appropriate decisions including the hedge decisions.
Due to the long-term nature of risks involved with the agricultural production, American options that perform well even with long duration maturity seem to be most suitable. Further Shah et al. 2009 shows that the liquidity costs are higher in options markets compared to futures markets due to low trading volumes causing high bid-ask spreads in the options market. Due to this for a hedger, who faces some uncertainty in the actual physical delivery of the commodity, it is least expensive to stay in futures market than in options market and in such cases, an early exercise of options might come handy.

Notes 1: Due to a structural break in guar seed price trend afflicted by its linkage to the crude oil market, price data only from the year 2014 is considered for calculating the seasonal index so that it reflects the new demand-supply structure for the commodity.

\section{REFERENCES}

Bjerksund, Petter and Stensland, Gunnar 2002. Closed-form valuation of American options, working paper, Department of Finance and Management Science NHH, Norway.

Black, Fischer 1976. The pricing of commodity contracts, Journal of Financial Economics, 3(1-2): 167-179.

Carter, Colin A. and Mohapatra, Sandeep 2008. How Reliable Are Hog Futures as Forecasts? American Journal of Agricultural Economics, 90(2): 367-378.

Gupta, Akanksha and Poornima Varma (2016): Impact of Futures Trading on Spot Markets: An Empirical Analysis of Rubber in India, Eastern Economic Journal, 42(3): 373-386.

Kumar, Brajesh and Pandey, Ajay 2013. Market efficiency in Indian commodity futures markets, Journal of Indian Business Research, 5(2): 101-121.

Lyuu, Yuh-Dauh 2002. Financial Engineering and Computation: Principles, Mathematics, Algorithms (Cambridge University Press)

McKenzie Andrew M., Bingrong Jiang, Harjanto Djunaidi, Linwood A. Hoffman and Eric J. Wailes 2002. Unbiasedness and Market Efficiency Tests of the U.S. Rice Futures Market, Review of Agricultural Economics, 24(2): 474-493.

Mohan, Sushil and Love, James 2004. Coffee futures: Role in reducing coffee producers' price risk, Journal of International Development, 16(7): 983-1002.

Press Information Bureau 2004. Futures trading in wheat and rice picks up, 9 Mar, Viewed on 22 March 2018 (http://pib. nic.in/newsite/erelcontent.aspx?relid=1282)

Ranganathan, Thiagu and Ananthakumar, Usha 2014. Market efficiency in Indian soybean futures markets, International Journal of Emerging Markets, 9(4): 520-534. 
Reuters 2012. India's NCDEX halts guar trading, 28 Mar, Viewed on 22 March 2018 (https://in.reuters.com/article/ india-guar-contract/update-2-indias-ncdex-halts-guartrading-idINL3E8ES2QC20120328)

Shah, S., Brorsen, B.W. and Anderson, K.B. 2009. Liquidity Costs in Futures Options Markets, Proceedings of the NCCC134 Conference on Applied Commodity Price Analysis, Forecasting, and Market Risk Management. St. Louis, MO.
Shastri, Kuldeep and Tondon, Kishore 1986. Options on futures contracts: a comparison of European and American pricing models, Journal of Futures Markets, 6(4): 593-618.

Shihabudheen, M.T. and Padhi, Puja 2010. Price discovery and volatility spill over effect in Indian commodity market, Indian Journal of Agricultural Economics, 65(1): 101-117. 